\title{
INVESTIGATION ON INDOOR ENVIRONMENTS OF RESIDENTIAL BUILDINGS IN ULAANBAATAR DURING WINTER
}

\author{
Studies on indoor environments and energy consumption of dwellings in Mongolia, Part 1 \\ ウランバートルにおける集合住宅の冬季室内熱環境の調査 \\ モンゴルに扔ける住宅の室内環境とエネルギー消費に関する研究 その 1 \\ Bilguun BUYANTOGTOKH ${ }^{* 1}$ and Qingyuan $Z$ HANG $^{* 2}$ \\ ビルグーン ブヤントゴトホ, 張＼cjkstart晴 原
}

\begin{abstract}
In this study we clarified indoor environments of residential buildings in Ulaanbaatar, Mongolia by questionnaire and measurement. Five structure types were considered in this study. Questionnaires were conducted for 374 apartments and 18 apartments were randomly selected from the surveyed apartments for measuring indoor air temperature, relative humidity and $\mathrm{CO}_{2}$ concentration. Ventilation rate of tested apartments was estimated based on the indoor $\mathrm{CO}_{2}$ concentration and heat loss coefficient of the apartments was compared according to structure types. Indoor environment of the residential buildings is typically hot and dry. Heat loss coefficient is high for non-insulated structures, which implies high potential of energy savings by thermal retrofitting.
\end{abstract}

\footnotetext{
Keywords : Structure types, Indoor thermal environment, Ventilation rate, Heat loss coefficient, Mongolia 構造タイプ，室内熱環境，換気，熱損失係数，モンゴル
}

\section{INTRODUCTION}

With the economic growth ${ }^{1)}$ in Mongolia, people's living standard has been improving. As a result, energy consumption for residences has increased, which contributes to severe air pollution and energy shortages in recent years.

Currently there are three coal-fired cogeneration power plants and one heat-only plant supplying thermal energy to the district heating network in Ulaanbaatar. Total thermal energy produced is 6,265 Tcal in 2016 ${ }^{2}$. All plants have reached their utmost capacity and there would be shortages ${ }^{3)}$ if energy consumption continues to increase. So energy conservation of residences is an urgent issue to deal with.

The purposes of our study are to make clear energy consumption and indoor environment of residences including residential buildings, gers and to give suggestions about energy saving measures based on surveying, testing and simulations.

So far there have been some studies on thermal environment of residential buildings in Ulaanbaatar. Ishikawa et al.4) investigated indoor environment of residential buildings with precast panel structure in Ulaanbaatar. Endo et al.5) investigated energy consumption and indoor environment of the residential building with insulated brick structure in Ulaanbaatar. They measured heat loss coefficient for the tested buildings. None of these studies, however, could cover all the structure types, therefore it is impossible for them to compare energy consumption by structure types.

In this paper as a part of a string of studies we focused on residential buildings in Ulaanbaatar with different types of structure and clarified indoor environment as well as heat loss coefficient by survey and measurement.

We conducted surveying for 374 apartments with different structure types in order to draw a general overview of apartments and households. Furthermore, 18 apartments are selected for measuring indoor environment elements such as air temperature, relative humidity and $\mathrm{CO}_{2}$ concentration. Ventilation rate was calculated using $\mathrm{CO}_{2}$ concentration data to
*1 Grad. Student, Institute of Urban Innovation, Yokohama National University, M.Eng.

* 2 Prof., Institute of Urban Innovation, Yokohama National University, Dr.Eng.
横浜国立大学都市イノベーション学府 大学院生・工修 横浜国立大学都市イノベーション研究院＼cjkstart教授・工博 


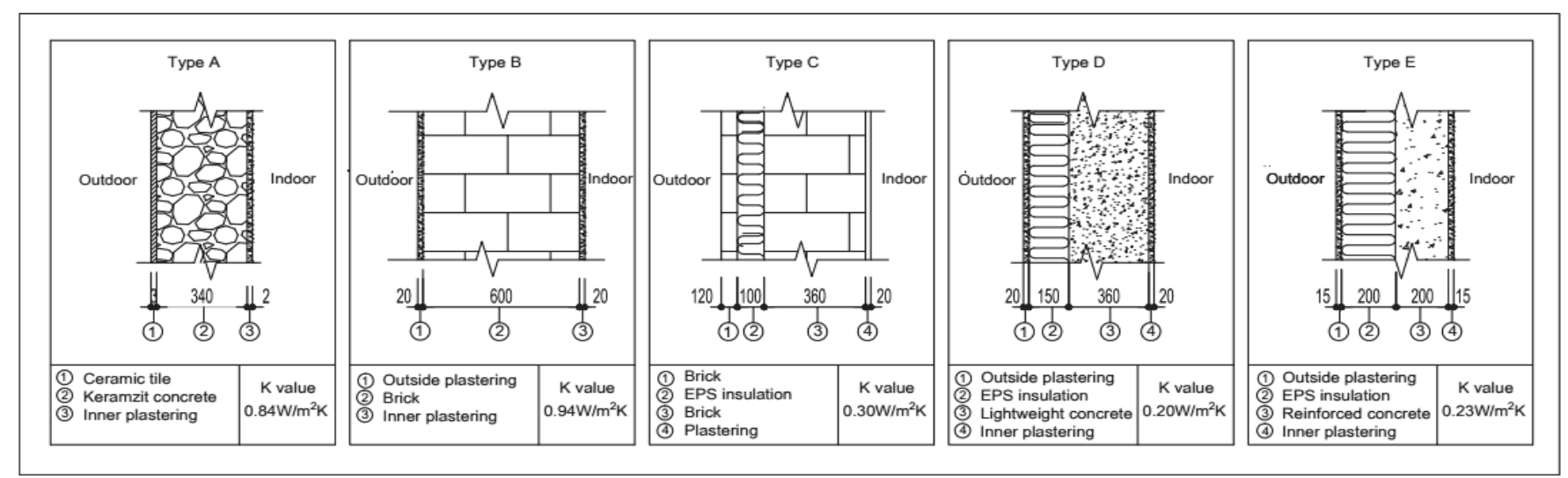

Fig.1 Cross sections of different structure types for the external walls

estimate heat loss through ventilation. Finally, heat loss coefficients of the residential buildings with different structure types were compared with each other.

\section{OUTLINE OF SURVEYING AND MEASUREMENT}

\subsection{History of residential buildings}

Ulaanbaatar has a history of more than 300 years as it was named with the meaning of the 'city of ger'6). Initally people of the Ulaanbaatar city used to live in gers that were felt insulated tents with wood frames. Even now people live in gers because of their convenience to build and affordable price. Right after the revolution in 1921 architecture and construction sector were developed rapidly in the process of modernization.

The earliest residential buildings were built in the 1950's with $640 \mathrm{~mm}$ thick brick walls. In 1970's the Soviet technology that used precast concrete panels for construction was introduced for residential buildings. Heat loss of these two structure types is large because there is no insulation on the external envelopes. In 1997 the building code was updated and thermal resistance requirement of the external envelopes were strengthened in order to save energy. All the buildings built after 1998 became insulated according to the code. After the year of 2000 insulated brick structure was introduced to Mongolia for residential buildings but did not last long because of its high labor consumption and heavy weight. In 2010 two types of new technologies were developed such as lightweight concrete block structure and full concrete structure with thermal insulation. These two technologies are considered the best up to now due to high thermal resistance and high resistance to the earthquakes. In 2014, $42.3 \%$ of total households in Ulaanbaatar live in residential buildings and the rest households live in detached houses and gers ${ }^{7}$. All the structure types mentioned above with their heat transfer coefficient are shown in Fig.1. Heat transfer coefficient is the smallest for Type $\mathrm{D}\left(0.20 \mathrm{~W} / \mathrm{m}^{2} \mathrm{~K}\right)$ while it is the largest for Type B $\left(0.94 \mathrm{~W} / \mathrm{m}^{2} \mathrm{~K}\right)$. The insulation material used for the external walls of types C, D and E is expanded polystyrene (EPS). Thickness of the insulation varies between $100 \mathrm{~mm}-200 \mathrm{~mm}$ depending on the type of the main structure as shown in Fig.1.

\subsection{Outline of surveyed and measured buildings}

Surveying was conducted in order to obtain general information about residential buildings and indoor thermal comfort of the residential buildings because the available statistical data was not sufficient. The questionnaire consists of general geometrical information, social information about households, thermal comfort and energy saving behavior of the households. Heating consumption was not asked in the questionnaire because thermal energy is paid based on the heated floor area and there is no heat meter for each apartment. More than 400 questionnaires were distributed to households in different residential buildings but 374 of them are fully answered. $48 \%$ of total 374 apartments are Type A and Type B buildings while $52 \%$ of them are Type C, Type D, Type E buildings. Eighteen of all surveyed apartments were randomly selected for measuring the indoor environment.

The outline of all the measured 18 apartments is summarized in Table 1. There are natural ventilation shafts in kitchens, toilets and bathrooms in all residential buildings as shown in Fig.2. Space heating devices such as radiators are installed in the buildings that connect with the district heating system except Type E. Thermal energy is supplied by a heat-only boiler for Type E.

Residents spend most of their time in living rooms during the day and in most cases living rooms were used as bedrooms at night due to a lack of bedrooms. So living rooms were chosen for measurement. The measuring period was divided into day and night because the activities were different. Measurements on indoor environments of the residential buildings were carried

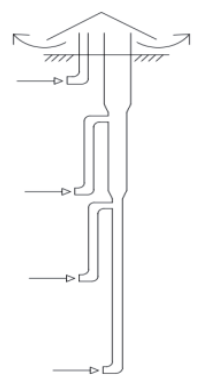

Fig.2 Natural ventilation shaft 


\begin{tabular}{|c|c|c|c|c|c|c|c|}
\hline Structure type & $\begin{array}{l}\text { 岕 } \\
\text { 䓂 } \\
\text { z }\end{array}$ & 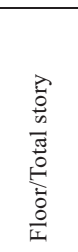 & 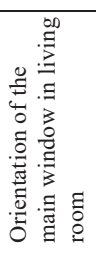 & 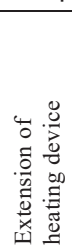 & 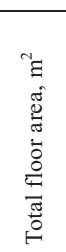 & 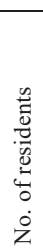 & 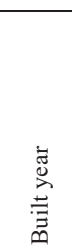 \\
\hline $\begin{array}{c}\text { Type A } \\
\text { (Precast concrete) }\end{array}$ & A1 & $3 / 5$ & $\mathrm{~N}$ & Yes & 60.5 & 5 & 1972 \\
\hline ; & $\mathrm{A} 2$ & $2 / 9$ & $\mathrm{~N}$ & No & 85.0 & 2 & 1986 \\
\hline $\begin{array}{l}\text { View of builing } \\
\text { with A3 }\end{array}$ & A3 & $8 / 9$ & E & Yes & 54.5 & 5 & 1987 \\
\hline $\begin{array}{c}\text { Type B } \\
\text { (Non-inlulated } \\
\text { Brick) }\end{array}$ & B1 & $2 / 5$ & $\mathrm{~S}$ & Yes & 54.7 & 5 & 2000 \\
\hline & B2 & $4 / 4$ & $\mathrm{E}$ & No & 52.0 & 2 & 1962 \\
\hline & B3 & $3 / 3$ & $\mathrm{E}$ & No & 86.0 & 4 & 1956 \\
\hline $\begin{array}{l}\text { View of builing } \\
\text { with B2 }\end{array}$ & B4 & $3 / 5$ & $\mathrm{~S}$ & No & 35.0 & 5 & 1990 \\
\hline $\begin{array}{c}\text { TypeC } \\
\text { (Insulated } \\
\text { brick) }\end{array}$ & C1 & $6 / 6$ & $\mathrm{E}$ & No & NA & 3 & 2000 \\
\hline 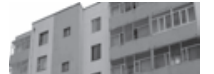 & $\mathrm{C} 2$ & $6 / 6$ & W & No & 56.0 & 3 & 2010 \\
\hline & C3 & $5 / 12$ & $\mathrm{E}$ & No & 58.0 & 4 & 2013 \\
\hline $\begin{array}{l}\text { View of builing } \\
\text { with C4 }\end{array}$ & C4 & $3 / 5$ & $\mathrm{~S}$ & No & 72.0 & 3 & 2004 \\
\hline $\begin{array}{c}\text { Type D } \\
\text { (Insulated light } \\
\text { weight block) }\end{array}$ & D1 & $11 / 12$ & $\mathrm{~N}$ & No & 47.0 & 4 & 2010 \\
\hline 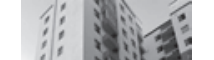 & D2 & $7 / 12$ & $\mathrm{E}$ & No & 40.0 & 3 & 2016 \\
\hline$y_{i}$ in & D3 & $11 / 12$ & $\mathrm{~S}$ & No & 48.0 & 2 & 2014 \\
\hline & D4 & $7 / 12$ & $\mathrm{~N}$ & No & 50.0 & 4 & 2013 \\
\hline $\begin{array}{l}\text { View of builing } \\
\text { with D3 }\end{array}$ & D5 & $7 / 12$ & $\mathrm{~N}$ & No & 59.0 & 5 & 2012 \\
\hline $\begin{array}{c}\text { Type E } \\
\text { (Insulated } \\
\text { concrete) }\end{array}$ & E1 & $4 / 12$ & W & No & 37.0 & 5 & 2016 \\
\hline $\begin{array}{l}\text { View of builing } \\
\text { with E1 and E2 }\end{array}$ & E2 & $9 / 12$ & W & No & 35.0 & 5 & 2016 \\
\hline
\end{tabular}

out during January - March, 2017. All of the 18 apartments were measured for seven days. Indoor air temperature, relative humidity and $\mathrm{CO}_{2}$ concentration were measured and recorded using data loggers (TR-76Ui, T\&D Corporation) in each living room at $1.0-1.5 \mathrm{~m}$ above floor level. Measuring interval was 10 minutes for each piece of equipment.

\subsection{Weather conditions during measurement periods}

Measurements of indoor environment were conducted during four periods, the outdoor air temperature and relative humidity during which are shown in Fig.3. The outdoor air temperature during the last period (Mar.13-19, 2017) was higher than that of other periods because of the change of the seasons.

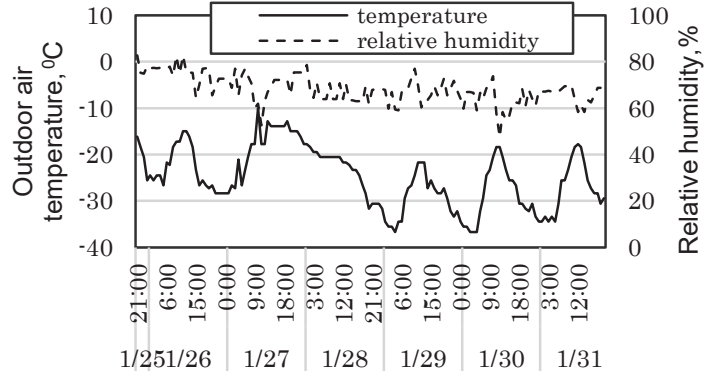

(a) The first period (Jan.25-31, 2017)

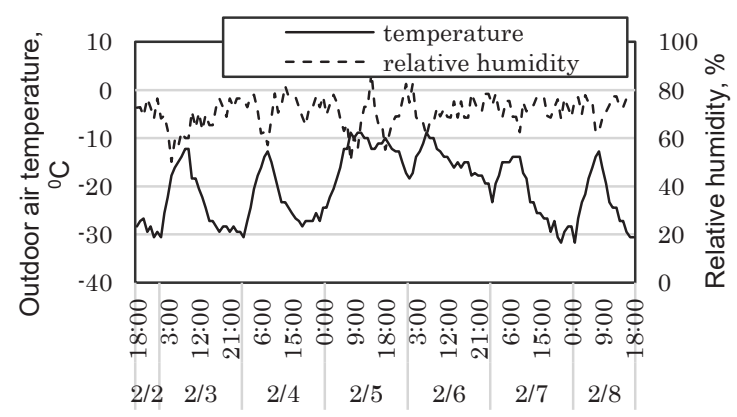

(b) The second period (Feb.2-8, 2017)

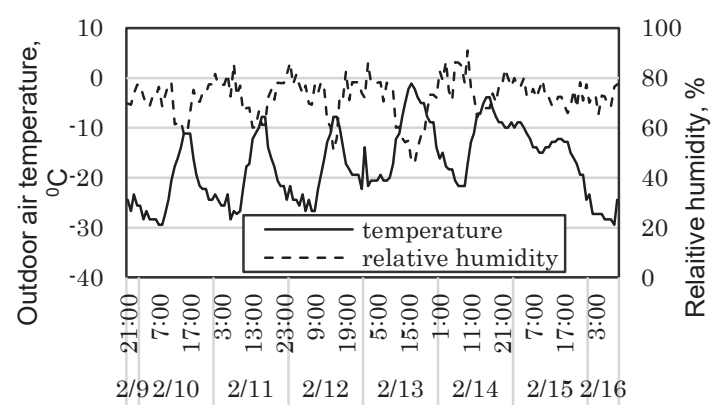

(c) The third period (Feb.9-16, 2017)

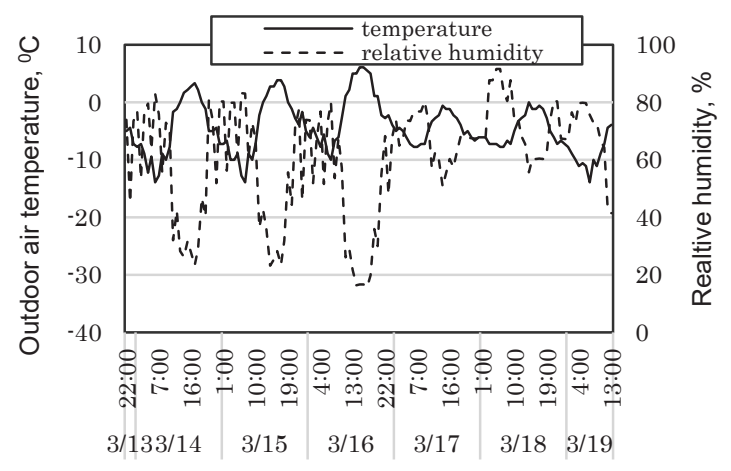

(d) The fourth period (Mar.13-19, 2017)

Fig.3 Outdoor air temperature and relative humidity during measurement periods

\section{RESULTS AND ANALYSES}

\subsection{Survey findings}

The households are composed of couples with their children, couples with their parents, households with their relatives, couple without children and single person. Surveyed household structure is shown in Fig.4. The percentage of couple with their children is larger than other groups. 
Number of residents can be found in Fig. 5 and households that have four to five residents account for the largest portion. Monthly incomes of the surveyed and measured households are shown in Fig.6, respectively. Monthly income of the measured households is equally divided into two groups such as $210-420$ USD and 420 - 840 USD while the income of the surveyed households is divided into four categories. The economic condition of tested households is slightly better than surveyed ones by chance.

Fig.7 shows the floor area of each surveyed and measured apartments. Floor area of the measured apartments is larger than those surveyed, which might be related to the household income shown in Fig.6.

The indoor thermal environment of each apartment was evaluated in questionnaires by residents. As seen in Fig.8, 28\% were very satisfied, $59 \%$ were satisfied and remaining $13 \%$ were dissatisfied with their indoor thermal environment.

\subsection{Analyses of measurement results}

\subsubsection{Indoor air temperature}

The measuring period was separated into day time (9:00-20:00) when some members go to work or to school, and night time (20:00 - 9:00) when all the members are gathered

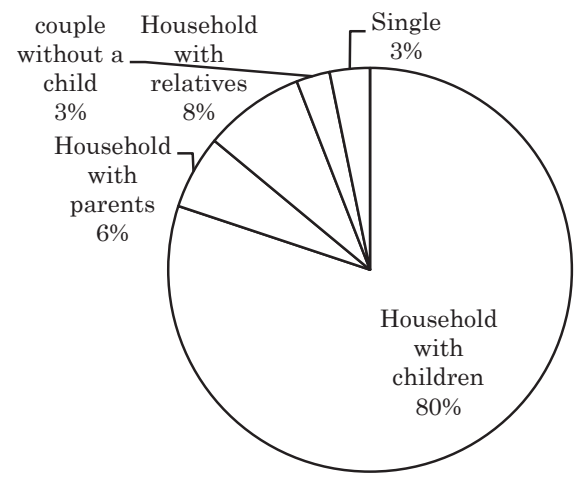

Fig.4 Household structure

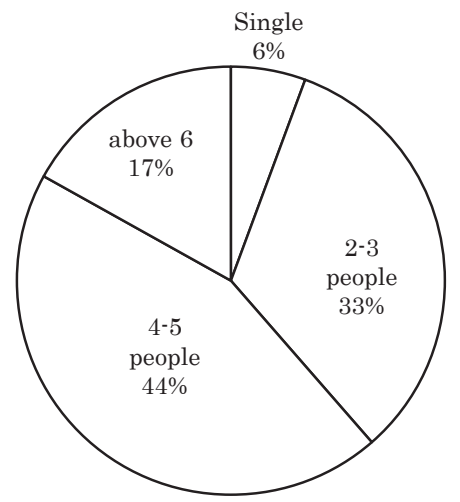

Fig.5 Resident number of households together at home. Fig.9 shows the standard deviations, maximum, minimum and average values of indoor air temperatures of the apartments. The average indoor air

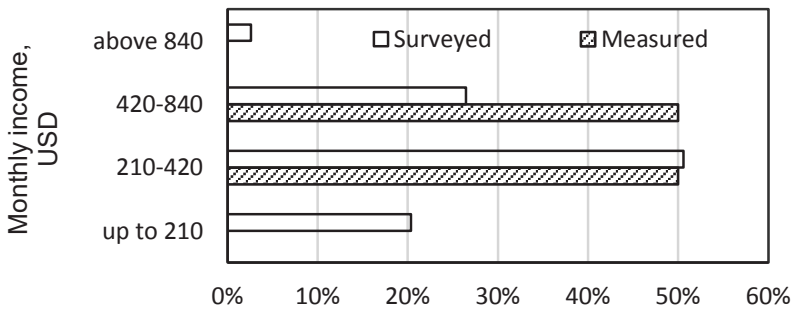

Fig.6 Monthly income of households

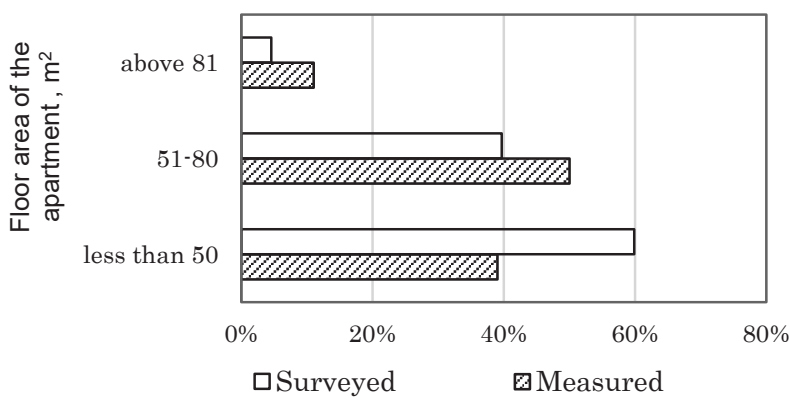

Fig.7 Floor area for an apartment

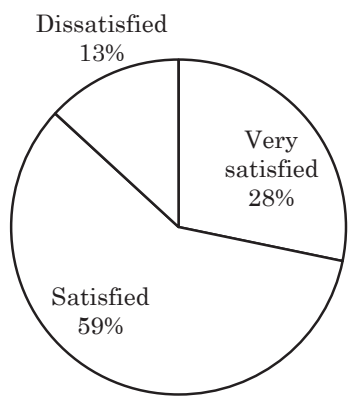

Fig.8 Evaluation of indoor thermal environment

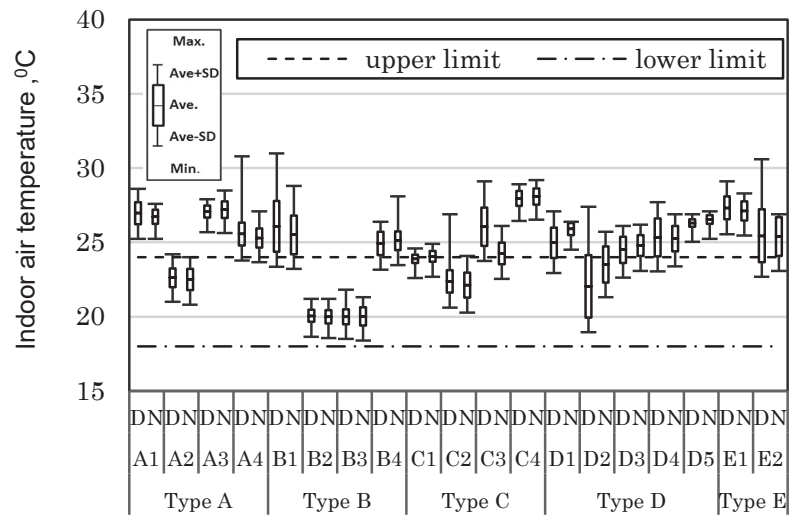

Fig.9 Indoor air temperature in day and night time ${ }^{*}$ D:Day time; N:Night time 


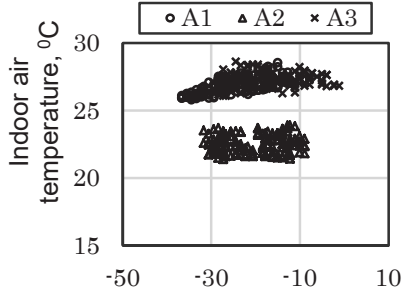

Outdoor air temperature, ${ }^{\circ} \mathrm{C}$

(a) Type A

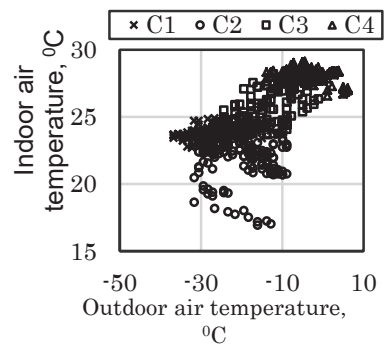

(c) Type C

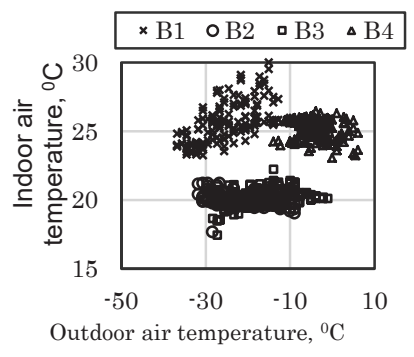

(b) Type B

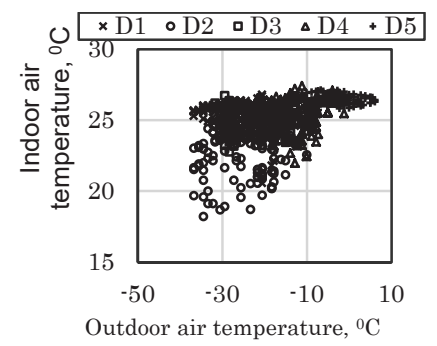

(d) Type D

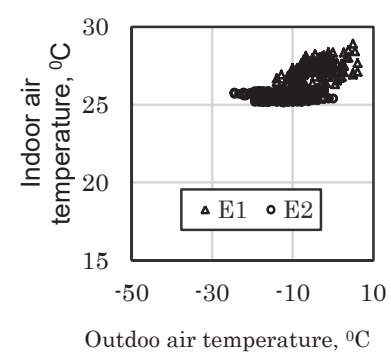

(e) Type E

Fig.10 Relationship between indoor and outdoor air temperatures

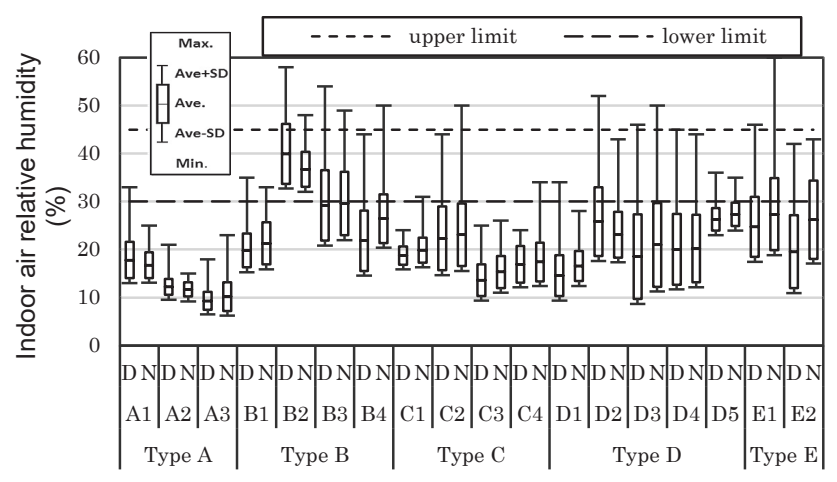

Fig.11 Indoor air relative humidity in day and night time

temperature of measured apartments is equal to $24.7^{\circ} \mathrm{C}$ throughout day and night time. The highest average air temperature for Type $\mathrm{C}$ is $27.9^{\circ} \mathrm{C}$, in contrary the lowest is $20.0^{\circ} \mathrm{C}$ for Type B apartments. The standard deviations of indoor air temperature during day time are larger than that of night time, which is assumed to be related to the air exchange behavior of the households. Households ventilate their apartments through opening windows occasionally when the indoor air temperature is too high or the residents want to let in fresh air. These periods can be identified by significant drops in room temperature. According to the national standard 8 , the upper limit air temperature should be $24^{\circ} \mathrm{C}$ while the accepted lower limit is $18^{\circ} \mathrm{C}$ for residential buildings. Indoor air temperature is higher than $24^{\circ} \mathrm{C}$ for $66.7 \%$, and between $18^{\circ} \mathrm{C}-24^{\circ} \mathrm{C}$ for the rest hours. The indoor air temperature differs even within the same structure type.

Fig.10 shows the relationship between indoor and outdoor air temperatures. Though the outdoor air temperature changes between $-37^{\circ} \mathrm{C}$ and $7^{\circ} \mathrm{C}$, the indoor air temperature is kept above $20^{\circ} \mathrm{C}$ in each apartment for most hours, which agrees with the studies of Ishikawa et al.4) and Endo et al.5) .

\subsubsection{Relative humidity}

We compared indoor relative humidity of the apartments in day and night time as shown in Fig.11. Average indoor relative humidity was between $9 \%-29 \%$ in day time and $10 \%-30 \%$ in night time, respectively, except for the B2 apartment. Relative humidity is lower than the national standard ${ }^{8)}$ level for most of the apartments. The highest average value in day time is $40 \%$ for B2 apartment and the lowest one is 9\% for A3 apartment. Relative humidity was comparatively high in B2 apartment because of lower air temperature shown Fig.9 and Fig.10 (b).

\subsubsection{Thermal comfort}

In order to clarify the indoor thermal environment of the apartments both indoor air temperature and relative humidity were plotted in the psychrometric chart by their structure types. Thermal comfort zone is drawn according to the ISO77309). In this paper, we distinguished zones that are out of comfort zone into five zones such as Hot zone, Hot - Dry zone, Dry zone, Cold Dry zone and Cold zone as shown in Fig.12. Table 2 shows the conditions of air temperature and relative humidity for the zoning of thermal comfort.

Fig.13 shows the thermal indoor environment of Type A apartments. All the plots for the three apartments are out of Comfort zone. Plots for apartments A1 and A3 are in Hot - Dry zone and that for A2 are in Dry zone. Residents of A1 and A3 apartments have extended their radiators by themselves. Household A2 apartment, however, has not extended the radiators as others did, so that heat emitted to the apartment is less than other apartments, which results in lower indoor air temperature.

Indoor thermal comforts of Type B apartments are given in Fig.14. Thermal environment is sometimes in Comfort zone and sometimes in Cold - Dry for B2 and B3 apartments as plotted in the psychrometric chart. Those two apartments have lowest air temperatures and highest relative humidity as shown in Fig.9 and Fig.11 accordingly. The lower room temperature for B2 and B3 apartments is caused by roofs that enhance heat loss. The plots for B1 and B4 apartments distribute in Dry, Hot-Dry and Hot zones. 


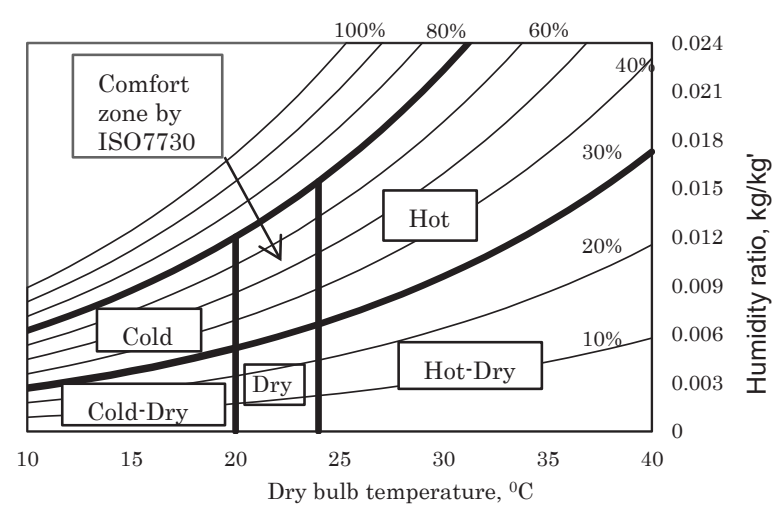

Fig.12 Thermal comfort zones

Table 2 Conditions for the zoning of thermal comfort

\begin{tabular}{|c|c|c|}
\hline Zone & $\begin{array}{c}\text { Indoor air temperature } \\
\theta,{ }^{\circ} \mathrm{C}\end{array}$ & $\begin{array}{c}\text { Relative humidity } \\
\varphi, \%\end{array}$ \\
\hline Hot & $\theta>24^{\circ} \mathrm{C}$ & $30 \%<\varphi<70 \%$ \\
\hline Hot-Dry & $\theta>24^{\circ} \mathrm{C}$ & $\varphi<30 \%$ \\
\hline Dry & $20^{\circ} \mathrm{C}<\theta<24^{\circ} \mathrm{C}$ & $\varphi<30 \%$ \\
\hline Cold-Dry & $\theta<20^{\circ} \mathrm{C}$ & $\varphi<30 \%$ \\
\hline Cold & $\theta<20^{\circ} \mathrm{C}$ & $30 \%<\varphi<70 \%$ \\
\hline
\end{tabular}

\section{\begin{tabular}{|c|}
\hline$\triangle \mathrm{A} 1$ \\
$\triangle \mathrm{A} 2$ \\
$\times \mathrm{A} 3$ \\
\hline
\end{tabular}}

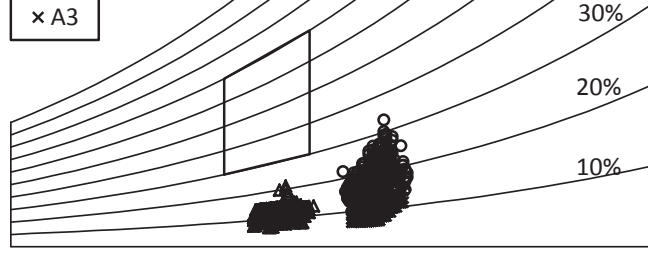

10

15

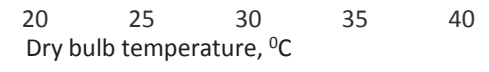

Fig .13 Thermal comfort of Type A apartments

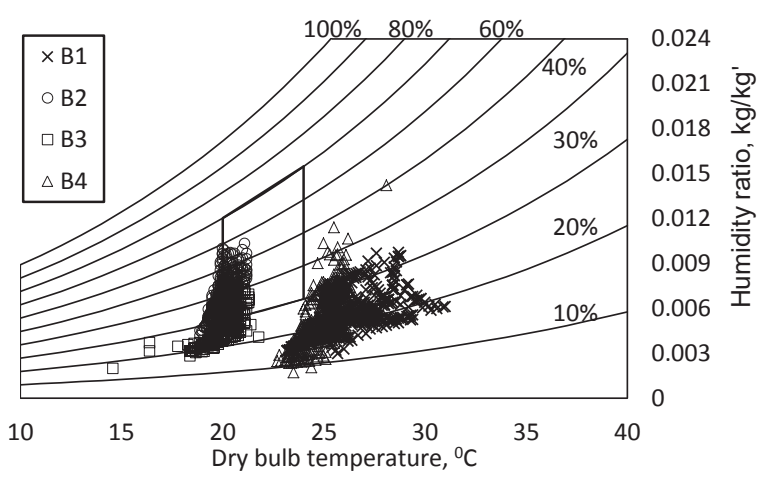

Fig.14 Thermal comfort of Type B apartments

Fig.15 shows the thermal environment of the Type C apartments. Plots for $\mathrm{C} 1, \mathrm{C} 3$ and $\mathrm{C} 4$ are in the Hot-Dry zone while that for $\mathrm{C} 2$ is divided into Comfort and Dry zones for most hours.

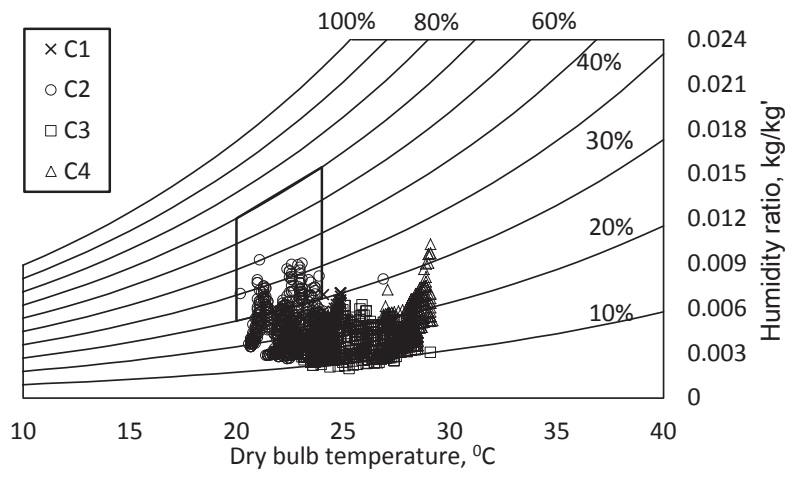

Fig.15 Thermal comfort of Type $\mathrm{C}$ apartments

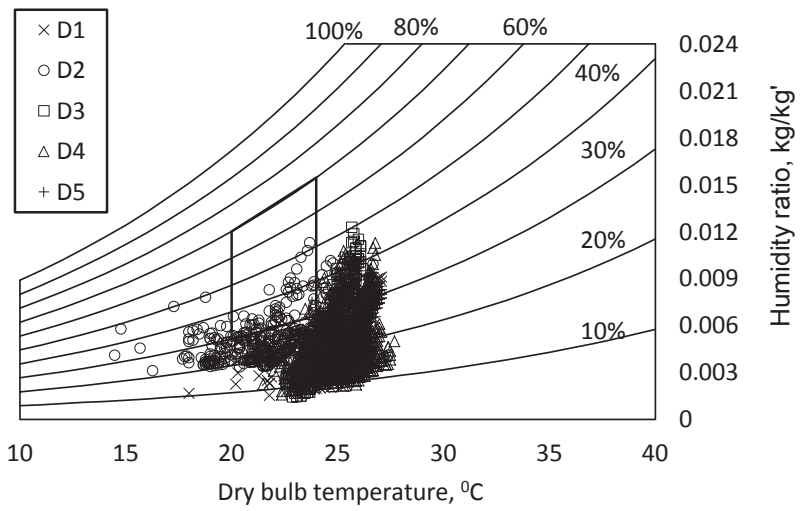

Fig.16 Thermal comfort of Type D apartments

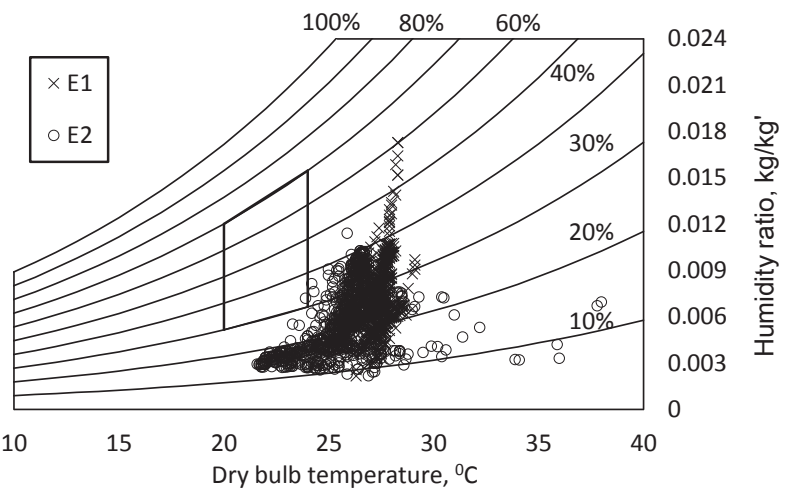

Fig.17 Thermal comfort of Type E apartments

Thermal comforts of the Type D apartments are shown in Fig.16. Plots for Type D apartments distribute widely in Hot, Hot - Dry and Dry zones while that for D2 apartment are in Comfort zone in most hours. Relative humidity for D2 is higher due to comparatively lower temperature.

The indoor environment of both E1 and E2 apartments is divided into Hot, Hot - Dry and Dry zones as seen in Fig.17. In some hours relative humidity increases significantly in E1 due to human activities such as cooking or shower.

Fig.18 shows the relationship between average indoor air temperature and satisfaction evaluation by the residents. Residents are satisfied or very satisfied when the room 
temperature is above $23^{\circ} \mathrm{C}$; some residents are dissatisfied when the room temperature is lower than $23^{\circ} \mathrm{C}$, such as residents in $\mathrm{A} 2$ and B3 apartments, though some residents are satisfied with the similar room temperature, such as residents in B2 apartment.

\subsection{4 $\mathrm{CO}_{2}$ concentration}

Because no gas is used in all the residential buildings people's exhale is the only source of $\mathrm{CO}_{2}$. Therefore, indoor $\mathrm{CO}_{2}$ concentration is influenced by the number of people who emits $\mathrm{CO}_{2}$ through exhaling. The number of people varies throughout a day. The average, maximum, minimum, and standard deviation values of the indoor air $\mathrm{CO}_{2}$ concentration for all type of buildings are shown in Fig.19. The average $\mathrm{CO}_{2}$ concentration is $972 \mathrm{ppm}$ during the day time and 1,134 ppm during night time, respectively, which is within the Mongolian standard ${ }^{10)}$. The maximum $\mathrm{CO}_{2}$ concentration is $1,835 \mathrm{ppm}$ during night time

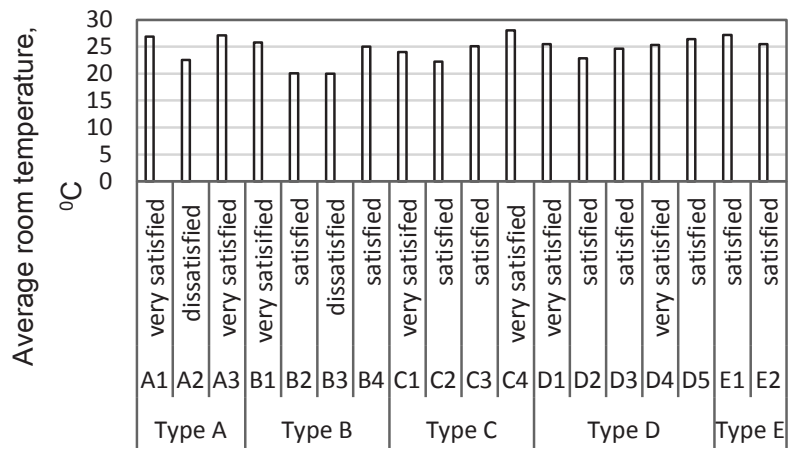

Fig.18 Average indoor air temperature and resident satisfaction

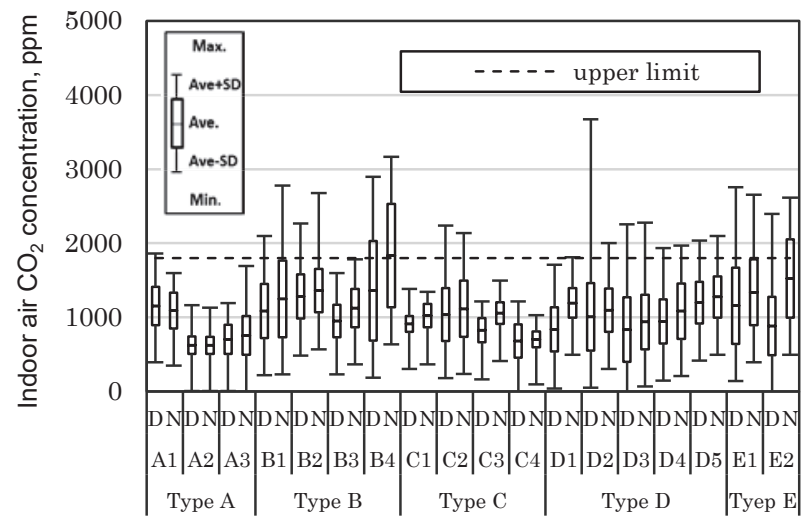

Fig.19 Indoor air $\mathrm{CO}_{2}$ concentration in day and night time

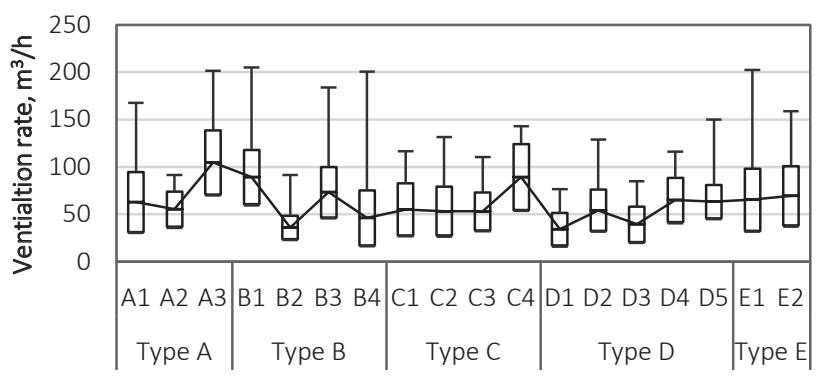

Fig.20 Ventilation rate of the apartments

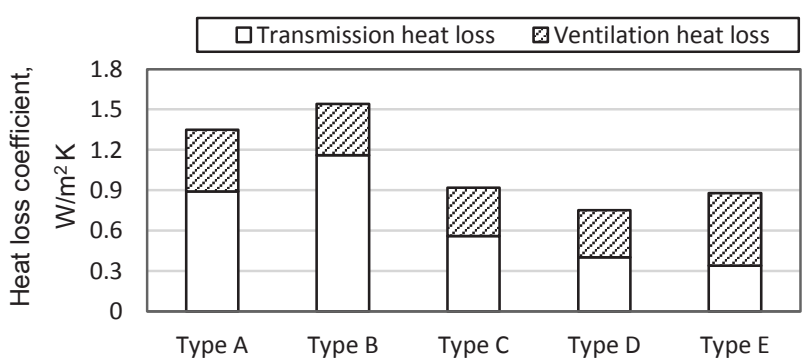

Fig.21 Heat loss coefficient by each type

Table 3 Values of heat loss coefficient by structure types

\begin{tabular}{|c|c|c|c|}
\hline $\begin{array}{c}\text { Structure } \\
\text { type }\end{array}$ & $\begin{array}{c}\text { Heat loss } \\
\text { coefficient by } \\
\text { transmission, } \\
\mathrm{W} /\left(\mathrm{m}^{2} \mathrm{~K}\right)\end{array}$ & $\begin{array}{c}\text { Heat loss } \\
\text { coefficient by } \\
\text { ventilation, } \\
\mathrm{W} /\left(\mathrm{m}^{2} \mathrm{~K}\right)\end{array}$ & $\begin{array}{c}\text { Heat loss } \\
\text { coefficient, } \\
\mathrm{W} /\left(\mathrm{m}^{2} \mathrm{~K}\right)\end{array}$ \\
\hline Type A & 0.89 & 0.45 & 1.34 \\
\hline Type B & 1.16 & 0.37 & 1.53 \\
\hline Type C & 0.56 & 0.35 & 0.91 \\
\hline Type D & 0.40 & 0.34 & 0.74 \\
\hline Type E & 0.34 & 0.52 & 0.86 \\
\hline
\end{tabular}

while it is $1,362 \mathrm{ppm}$ during the day time. The minimum $\mathrm{CO}_{2}$ concentration is $624 \mathrm{ppm}$ which does not differ significantly during day and night time for A2 apartment. In some cases living rooms are used as bedrooms in the night time due to lack of bedrooms. Those apartments have higher $\mathrm{CO}_{2}$ concentration during the night time than day.

\section{ESTIMATION OF VENTILATION RATE AND HEAT LOSS COEFFICIENT}

As mentioned in Section 2.2 natural ventilation shafts are installed in the kitchens and restrooms of the residential buildings. Exhausted air flows through the vertical shaft with the stack effect. Residents sometimes open windows to adjust room temperature and let in fresh air. One of the purposes of this study is to clarify ventilation rates by the natural ventilation system. Therefore, the period when the window is open is excluded from the results. The period of opening windows is judged by the sudden drop of $\mathrm{CO}_{2}$ concentration. Ventilation rate of each apartment was estimated by Equation (1)11).

$$
V=\frac{m}{\left(p-p_{0}\right) \cdot 10^{-6}}
$$

where, $V$ is the ventilation rate in $\mathrm{m}^{3} / \mathrm{h} ; m$ is $\mathrm{CO}_{2}$ emission through exhaling in $\mathrm{m}^{3} / \mathrm{h} ; p$ is $\mathrm{CO}_{2}$ concentration in indoor air in ppm; $p_{0}$ is $\mathrm{CO}_{2}$ concentration in outdoor air in ppm.

The ventilation rate estimation results of 18 apartments are given in Fig.20. The average ventilation rate is $59 \mathrm{~m}^{3} / \mathrm{h}$, the maximum is found in A3 apartment equaling to $105 \mathrm{~m}^{3} / \mathrm{h}$, the 
minimum is found in D1 apartment equaling to $34 \mathrm{~m}^{3} / \mathrm{h}$. It is hard to say that the ventilation rate is similar within the same type according to Fig.20. Because even though the building type is the same, the building quality may differ depending on the year it was built, maintenance, construction technology etc. According to its definition, the heat loss coefficient of the apartments is estimated by Equation (2) using the heat transfer coefficient of the building envelops given in Fig. 1 and ventilation rate given in Fig.19.

$$
Q=\frac{\sum\left(k_{i} \cdot A_{i}\right)}{A_{f}}+\frac{c_{p} \cdot \rho \cdot V}{3600 \cdot A_{f}}
$$

where, $Q$ is heat loss coefficient in W/ $\mathrm{m}^{2} \mathrm{~K} ; k_{i}$ is heat transfer coefficient of the external wall in $\mathrm{W} / \mathrm{m}^{2} \mathrm{~K} ; A_{i}$ is surface area of each external envelope in $\mathrm{m}^{2} ; A_{f}$ is floor area of the apartment in $\mathrm{m}^{2} ; c_{p}$ is specific heat capacity of air in $\mathrm{J} / \mathrm{kgK} ; \rho$ is the air density in $\mathrm{kg} / \mathrm{m}^{3}$.

The average heat loss coefficient for measured apartments is compared in Fig.21 and Table 3. The heat loss coefficient for insulated types $\mathrm{C}, \mathrm{D}$ and $\mathrm{E}$ is less than $1.0 \mathrm{~W} / \mathrm{m}^{2} \mathrm{~K}$, while that for the uninsulated types A and B is larger than $1.0 \mathrm{~W} / \mathrm{m}^{2} \mathrm{~K}$. Heat loss through ventilation is the largest for Type E, though the ventilation rate shown in Fig.20 is not particularly large. This is because the floor area of Type $\mathrm{E}$ is smaller than other types, which enlarges heat loss by ventilation per square meter of the floor area. According to Fig.21, 25\% to $65 \%$ of total heat is lost through ventilation in residential buildings in Ulaanbaatar. The maximum heat loss coefficient for Type B is 1.8 times higher than that of the minimum for Type $\mathrm{D}$, which implies that there will be approximately $45 \%$ energy saving if heat loss coefficient of Type B is reduced to $0.74 \mathrm{~W} / \mathrm{m}^{2} \mathrm{~K}$ as Type $\mathrm{D}$.

\section{CONCLUSIONS}

In this study, we conducted surveying for 374 apartments with different structure types, and selected 18 apartments for measuring indoor thermal environment. The main findings from this study are:

- The indoor air temperature of the residential building is higher while relative humidity is lower than the Mongolian standard as well as ISO 7730 standard for most hours;

- Energy savings can be achieved by lowering the temperature in Hot - Dry and Hot zones to adequate level. In order to realize this, extension of radiators by the residents should be prohibited by rules;
- Average indoor $\mathrm{CO}_{2}$ concentration is between $624 \mathrm{ppm}$ and 1,835 ppm which is nearly within the Mongolian standard;

- Ventilation rate by the natural ventilation system is between $34 \mathrm{~m}^{3 / \mathrm{h}}-105 \mathrm{~m}^{3 / \mathrm{h}}$;

- Heat loss coefficient is between $0.74 \mathrm{~W} / \mathrm{m}^{2} \mathrm{~K}$ and $1.53 \mathrm{~W} / \mathrm{m}^{2} \mathrm{~K}$ for residential buildings. Significant energy savings can be expected for Type A and B by thermal retrofitting.

\section{ACKNOWLEDGEMENTS}

This work was supported by the Sasakawa Scientific Research Grant from The Japan Science Society.

\section{REFERENCES}

1) The World Bank: National accounts data, Retrieved from http://data.worldbank.org/indicator/NY.GDP.MKTP.KD.ZG?locations $=\mathrm{MN}$ accessed 2017.06.01

2) Ministry of Energy: Production data of energy sector (in Mongolian), retrieved from http://energy.gov.mn/c/572 accessed 2017.05.22

3) D. Delgertsogt, G, Purevdorj, R.Khaidav: Heating, Sustainable development strategy of district heating network in Ulaanbaatar, (in Mongolian), retrieved from http://mongolenergy.mn/images/medeelel/strategy.pdf, accessed 2017.06.14

4) Shohei Ishikawa, Masamichi Inai, Hirofumi Hayama, Koki Kikuta: Survey report for indoor environment of building in Ulaanbaatar city, Mongolia (in Japanese), Report on the annual meeting of the Society of Heating, Air-Conditioning Sanitary Engineers of Japan, pp.445-448, 2007

5) Suguru Endo et al: Study on indoor thermal environment and energy consumption for heating in Ulan Bator, Mongolia (in Japanese), Proceedings of 2014 Annual Meeting of Hokkaido Chapter of AIJ, Vol (87), pp.203-206, 2014

6) Master planning agency of capital city: Construction history of Ulaanbaatar city (in Mongolian), 2014

7) State housing corporation of Mongolia: Household and population survey in Ulaanbaatar, (in Mongolian) retrieved from http://tosk.gov.mn/4070.html, accessed 2017.03.29

8) Mongolian Agency for Standardization and Metrology: MNS4585:2007 Air quality General technical requirement (in Mongolian)

9) International organization for standardization: 2005 Ergonomics of the thermal environment, Analytical determination and interpretation of thermal comfort using calculation of the PMV and PPD indices and local thermal comfort criteria

10) Mongolian Agency for Standardization and Metrology: MNS5825: 2007 Residential and public building. Indoor micro climate (in Mongolian)

11) Shunroku Tanaka et al: The newest architectural environment engineering, $4^{\text {th }}$ Edition, Inoue Shoin, 2014 


\section{和文要約}

\section{1. はじめに}

モンゴルの経済成長に伴い人々の生活水準が向上してきている。 その結果、住宅におけるエネルギー消費が増大し、深刻な大気污染 に加担している。したがって住宅の省エネルギーが重要な課題であ る。

本研究の目的はアンケート調査、室内環境測定とシミュレーショ ンによって住宅の室内環境とエネルギー消費量を明らかにし、省エ ネルギーのための提言を行うことである。本報ではウランバートル における集合住宅を対象とし、まず 374 の住戸に対してアンケート 調査を行い、住宅の建築属性、居住者属性と温熱環境に対する満足 度を調べた。次にアンケート調查住戸のうち、18 住戸をランダムに 選び、7 日間にわたって室内温度、湿度と $\mathrm{CO}_{2}$ 濃度を測定し、室内 温熱環境と構造タイプ別の熱損失係数を求めた。

\section{2. 研究対象となる住宅の概要}

モンゴルの集合住宅は歴史的な理由で構造的に次の 5 つのタイブ に分類される(Table 1)。タイプ A : 無断熱プレキャストコンクリー 卜構造、タイプ B : 無断熱煉瓦構造、タイプ C : 断熱した煉瓦構造、 タイプ $\mathrm{D}$ : 断熱した軽量コンクリート構造、タイプ $\mathrm{E}:$ 断熱した普 通コンクリート構造。

室内の環境測定を行った住戸の概要を Fig.1 に示す。また、各住 戸の浴室、トイレと厨房に自然換気システムの排気口を設置してい る(Fig.2)。

また、4つの期間にわたり測定を行っており、測定期間における 外気温と相対湿度を Fig.3 に示す。

\section{3. アンケート調查と測定結果}

アンケート調査の結果を Fig. 4 Fig.8 に示す。対象となる一般の 住宅・世帯像が夫婦と子供の世帯が最も多く、世帯人数が $4 \sim 5$ 人、 月収が約 $420 U S D 、$ 床面積が $80 \mathrm{~m}^{2}$ 以下であることがわかった。また、 88\%の住民が温熱環境に満足している。

18 住戸を対象に温度湿度と $\mathrm{CO}_{2}$ 濃度を 10 分間隔で測定した。モ ンゴルの室内環境基準では、冬季設計室温の上限と下限はそれぞれ $24^{\circ} \mathrm{C}$ と $18^{\circ} \mathrm{C}$ であ。測定対象住戸の平均温度は $24.7^{\circ} \mathrm{Cで、} 66.7 \%$ の 時間帯において $24^{\circ} \mathrm{C}$ を回り、他の時間帯においては $18^{\circ} \mathrm{C} \sim 24^{\circ} \mathrm{C}$ の範囲内である。また、タイプの相違による室温の違いは顕著では ない(Fig.9)。Fig.10 に示すように、外気温が-3 $37^{\circ} \mathrm{C} \sim 7^{\circ} \mathrm{C}$ で変動して いるが室温は変動が小さくほとんどの時間帯において $20^{\circ} \mathrm{C}$ 以上であ る。

測定期間中における平均相対湿度は $22 \%$ あり、タイプ間の違い はほとんど見られない。B2 住戸の相対湿度は他より高くなっている が、それは乾球温度が低いためである（Fig.11）。

ISO7730による快適域に基づいて、湿り空気線図の領域を温度と 湿度によって Comfort Zone、Hot Zone、Hot-Dry Zone、Dry Zone、
Cold-Dry Zone、Cold Zone にゾーニングした(Fig.12 と Table 2)。 各住戸の時間ごとの温度と湿度を湿り空気線図にプロットし、 ISO7730 による快適域と併せて Fig.13〜 Fig.17 に示す。ほとんどの 住宅は Hot Zone または Hot-Dry Zone に入っている。

Fig.18 は平均室温と居住者の温熱環境に対する満足度の関係を示 す。平均室温が $23^{\circ} \mathrm{C}$ 以の場合、居住者は「満足」あるいは「大変 満足」となっているが、 $23^{\circ} \mathrm{C}$ 以下になると居住者が「満足」と「不 満」に分かれている。

室内 $\mathrm{CO}_{2}$ 濃度の測定結果を Fig.19 に示す。日中と夜間のリビン グの平均 $\mathrm{CO}_{2}$ 濃度はそれぞれ $972 \mathrm{ppm}$ と $1,134 \mathrm{ppm}$ であり、モン ゴル住宅の $\mathrm{CO}_{2}$ 濃度基準值の $1,800 \mathrm{ppm}$ 以下である。

\section{4. 換気量と熱損失係数の推定}

ウランバートルのほとんどの住宅ではガスが使用されていないた め、居住者の呼吸が $\mathrm{CO}_{2}$ の唯一の発生源となっている。したがって、 $\mathrm{CO}_{2}$ の測定值と在室者による $\mathrm{CO}_{2}$ 発生量を式(1)に代入すれば換気量 が求められる。居住者が時々過熱した室内温度を下げるために空を 開放し換気を行っているが、それらの時間帯のデータを除いて自然 換気システムの換気量を求めている。

測定対象となっている 18 住戸の換気量の平均值、標準偏差、最大 值と最小值は Fig.20 に示す。これらの住戸の平均換気量は $59 \mathrm{~m}^{3} / \mathrm{h}$ となっており、構造のタイプによる違いが顕著でない。

各住戸の換気量推定值および外壁の熱貫流率平均值を式(2)に代 入すれば、これらの住戸の熱損失係数が求められ、Fig.21 と Table 3 に示す。タイプ $\mathrm{A}$ からタイプ $\mathrm{E}$ までの熱損失係数の範囲は 0.74 $\mathrm{W} /\left(\mathrm{m}^{2} \cdot \mathrm{K}\right) \sim 1.53 \mathrm{~W} /\left(\mathrm{m}^{2} \cdot \mathrm{K}\right)$ となっている。熱損失係数が最大とな るタイプ $\mathrm{B}($ 無断熱煉瓦構造)が最小であるタイプ $\mathrm{D}($ 断熱した軽量コ ンクリート構造)の 1.8 倍にもなり、無断熱集合住宅の断熱改修によ る省エネルギー効果が期待できる。

\section{5. 結論}

本研究で得られた結論は以下の通りである。

・ ほとんどの時間帯において ISO7730 の快適基準またはモンゴル の室内環境基準に比べ室温が高く湿度が低い。

・省エネルギーために、室温を快適域またはモンゴルの室内環境基 準までに下げるべきであり、ルール等によって利用者によるラジ エーターの増設を制限すべきである。

- 室内の $\mathrm{CO}_{2}$ 濃度がほとんどの時間帯において基準值の 1,800ppm 以下であり、モンゴルの室内環境基準を満たしている。

・ 自然換気システムによる換気量は $34 \mathrm{~m}^{3} / \mathrm{h} \sim 105 \mathrm{~m}^{3} / \mathrm{h}$ となって いる。

- 熱損失係数は $0.74 \mathrm{~W} /\left(\mathrm{m}^{2} \cdot \mathrm{K}\right) \sim 1.53 \mathrm{~W} /\left(\mathrm{m}^{2} \cdot \mathrm{K}\right)$ であり、無断熱 集合住宅(タイプ $\mathrm{A}$ とタイプ $\mathrm{B}$ )の断熱改修による省エネルギー効 果が期待できる。 